\title{
PENGARUH KEMAMPUAN KERJA DAN MOTIVASI KERJA TERHADAP KINERJA MEMBER ORIFLAME DI BALI TAHUN 2017
}

\author{
Bagus Jaka Sugiharta \\ Jurusan Pendidikan Ekonomi, Fakultas Ekonomi \\ Universitas Pendidikan Ganesha Singaraja, \\ Indonesia \\ e-mail: jaka.bagus@ymail.com
}

\begin{abstract}
Abstrak
Penelitian ini bertujuan untuk mengetahui pengaruh kemampuan kerja terhadap kinerja member Oriflame di Bali, pengaruh motivasi kerja terhadap kinerja member Oriflame di Bali, dan pengaruh kemampuan kerja dan motivasi kerja terhadap kinerja member Oriflame secara bersama-sama. Populasi penelitian ini adalah member Oriflame di Bali pada salah satu grup yang masih aktif dari bulan Januari sampai dengan Maret 2017 dengan sampel sebanyak 95 responden. Penelitian ini mengunakan probability sampling dengan metode disproportionate areal random sampling. Pengumpulan data mengunakan kuesioner dan dianalisis mengunakan program SPSS. Hasil penelitian menunjukan bahwa terdapat pengaruh yang signifikan dari kemampuan kerja terhadap kinerja member Oriflame besar koefisien regresinya adalah 0.212 , terdapat pengaruh yang signifikan dari motivasi kerja terhadap kinerja member Oriflame dengan koefisien regresi sebesar 0.125 , dan pengaruh yang diberikan oleh kemampuan kerja dan motivasi kerja terhadap kinerja adalah sebesar $20.4 \%$.
\end{abstract}

Kata kunci: kemampuan, motivasi, kinerja member Oriflame

\begin{abstract}
This research aimed to find out the influence of work skill toward the performance of Oriflame's members in Bali, the influence of work motivation toward the performance of Oriflame's member in Bali and the influence of work skill and work motivation toward the performance of Oriflame's members simultaneosly. The population of this research is that Oriflame's members in Bali in one of active groups from January until March 2017 by using 95 respondents as sample. This research used probability sampling along with disproportionate areal random sampling method. Data collection used questionnaire that was analyzed by using SPSS program. The result of this research showed that there is significant influence of work skill toward the performance of Oriflame members, the regression coefficient is about 0.212 , there is significant influence of work motivation toward the performance of Oriflame's members with the regression coefficient is about 0.125 , and the influence of work skill together with work motivation toward the performance is about $20.4 \%$
\end{abstract}

Keywords: skill, motivation, performance of Oriflame's members

\section{PENDAHULUAN}

Setiap manusia mempunyai potensi untuk bertindak dalam berbagai bentuk aktivitas. Kemampuan bertindak itu dapat diperoleh manusia baik secara alami atau dipelajari. Walaupun manusia mempunyai potensi untuk berperilaku tertentu tetapi perilaku itu hanya diaktualisasi pada saat-saat tertentu saja. Potensi untuk berperilaku tertentu itu disebut ability (kemampuan), sedangkan ekspresi dari potensi ini dikenal sebagai performance (kinerja) yang artinya hasil kerja secara kualitas dan kuantitas yang dicapai oleh seorang pegawai dalam melakukan tugasnya sesuai dengan tanggung jawab yang diberikan kepadanya (Mangkunegara, 2007:67). Istilah kinerja berasal dari kata Job Performance atau Actual Performance (prestasi kerja atau prestasi sesungguhnya yang dicapai oleh seseorang), Sutrisno (2007:164) menyatakan bahwa prestasi atau kinerja adalah sebagai hasil kerja yang telah dapat dicapai seseorang dari tingkah laku kerjanya dalam 
melaksanakan aktivitas kerja. Untuk mengetahui kinerja karyawan dalam melaksanakan tugas-tugas yang menjadi tangung jawab karyawan, maka perlu dilakukan penilaian terhadap kinerja karyawan. Penilaian kinerja bertujuan untuk menilai seberapa baik karyawan sudah melaksanakan tugas dan apa yang harus mereka lakukan untuk menjadi lebih baik di masa mendatang. Ini dilaksanakan dengan merujuk pada isi pekerjaan yang mereka lakukan dan apa yang mereka harapkan untuk mencapai setiap aspek dari pekerjaan mereka. Kinerja adalah suatu hasil atau tingkat keberhasilan seseorang secara keseluruhan selama periode tertentu didalam melaksanakan tugas dibandingkan dengan berbagai kemungkinan, seperti standar hasil kerja, target atau sasaran yang telah ditentukan terlebih dahulu dan telah disepakati bersama (Rivai \& Basri, 2005).

Dalam sebuah usaha atau bisnis, kinerja karyawannya merupakan faktor yang sangat penting untuk mencapai tujuan dari pada perusahaan atau bisnis itu sendiri. Sulistiyani (2003:223) mengartikan prestasi atau kinerja sebagai kombinasi dari kemampuan, usaha dan kesempatan yang dapat dinilai dari hasil kerjanya, sehingga dapat di simpulkan bahwa keberhasilan suatu usaha atau bisnis dapat dipengaruhi oleh kinerja karyawan dari perusahaan itu sendiri. Menurut Mangkunegara (2005:13-14), terdapat 2 faktor yang mempengaruhi kinerja karyawan yaitu faktor kemampuan (Ability) dan faktor Motivasi (Motivation).

Kemampuan atau abilities ialah bakat yang melekat pada seseorang untuk melakukan suatu kegiatan secara fisik atau mental yang ia peroleh sejak lahir, belajar, dan dari pengalaman (Soehardi, 2003:24), selain itu kemampuan adalah kapasitas seorang individu untuk melakukan beragam tugas dalam suatu pekerjaan (Robbins dan Stephen, 2008). Kemampuan dapat dibagi menjadi dua tipe kemampuan antara lain kemampuan intelektual dan kemampuan fisik. Kemampuan intelektual adalah kemampuan yang dibutuhkan untuk melakukan berbagai aktivitas mental seperti berpikir, menalar, dan memecahkan masalah. Kemampuan fisik adalah kemampuan menjalankan tugas-tugas yang menuntut stamina, keterampilan, kekuatan, dan karakteristik serupa (Robbins dan Stephen, 2008). Kemampuan kerja merupakan kapasitas yang dimiliki seseorang untuk melakukan suatu pekerjaan yang ingin maupun tidak ingin dilakukannya menyangkut fisik maupun mental dari orang yang bersangkutan (Moenir, 2002). Kapasitas individu untuk mengerjakan berbagai tugas dalam suatu pekerjaan tidak sama antara yang satu dengan yang lainnya, hal ini disebabkan karena perbedaan kemampuan dari masingmasing orang. Terkadang seseorang mampu melakukan suatu pekerjaan yang tidak mampu dilakukan oleh orang lain karena perbedaan kemampuan yang dimiliki.

Kemampuan kerja yang dimiliki pegawai akan sangat menentukan keberhasilan organisasi dalam upayanya meraih sasaran dan tujuan yang telah ditetapkan. Moenir, (2002:86) mendefinisikan kemampuan dalam hubungannya dengan pekerjaan adalah suatu keadaan pada diri seseorang dengan penuh kesungguhan berdaya guna dan berhasil guna melaksanakan pekerjaan sehingga menghasilkan sesuatu yang optimal. Simpulan yang dapat di ambil dari beberapa pendapat ahli diatas adalah, kemampuan merupakan kecakapan yang dimiliki seseorang untuk melakukan suatu pekerjaan yang menyangkut kegiatan fisik maupun mental.

Dalam penelitian ini indikatorindikator kemampuan kerja difokuskan pada teori yang dikemukakan oleh Winardi (2002) yang teridiri dari dimensi 3 dimensi yaitu keterampilan, pengetahuan, dan pengalaman kerja. Keterampulan (skill) adalah keterampilan dan kecakapan pegawai 
sebagai akumulasi dari bakat dan kepribadian yang dimilikinya. Indikator Skill meliputi: mampu menyelesaikan tugas tepat pada waktunya, kreatif, inovatif, dan memiliki kemampuan untuk menghitung dengan cepat dan mengoperasikan komputer. Pengetahuan (knowledge) adalah pengetahuan yang dimiliki sebagai hasil pendidikan, pengalaman, dan pelatihan di bidang kerjanya. Indikator knowledge meliputi: Berlatar belakang pendidikan yang sesuai dengan bidang kerjanya dan sering mengikuti pelatihan di bidangnya. Pengalaman Kerja (Work Experience) adalah pengalaman kerja yang dimiliki pegawai. Indikator pengalaman kerja meliputi: Menguasai pekerjaan dengan baik, frekuensi kepindahan tempat kerja tinggi.

Motivasi berasal dari istilah latin yang berarti bergerak. Sebuah definisi umum yang dapat diterima menyebutkan bahwa motivasi merujuk kepada proses-proses dimana tingkah laku diaktifkan dan diarahkan, dan proses-proses ini bervariasi dalam arah, intensitas, dan durasinya pada masingmasing individu. Ada dua kategori utama teori yang cenderung melihat motivasi bersifat mekanistik atau kognitif. Analisis mekanistik melihat tingkahlaku ada, karena dimulai baik oleh adanya stimulus eksternal, misalya rasa haus. Kemudia kita menjadi bereaksi. Kita menggerakkan jari-jari kita dari kompor yang panas atau kita melakukan apapun untuk mendapatkan air untuk menghilangkan rasa haus. Jika respon mendatangkan hasil yang diinginkan, ia menjadi kebiasaan. Hamilton menyatakan bahwa pendapat yang demikian itu tidaklah tepat, karena teori ini tidak memasukkan penjelasan tentang "exploratory drive", yaitu suatu kebutuhan indera atau stimulasi perseptial atau pencarian informasi. Teori Kognitif menganggap bahwa berfikir tentang informasi yang akan masuk serta faktor lain yang akan turut berpengaruh sebagai hal penting untuk menentukan respons tingkah laku terhadap stimulus. Missalnya, sikap pribadi seseorang dan pengaruh- pengaruh sosial sangatlah penting dalam pengambilan keputusan dan demilikan pula menyangkut motivasi. Winardi (2007:7), menyatakan bahwa problem inti motivasi yang berkaitan dengan manajer organisasi adalah bagaimana cara merangsang sekelompok orang yang memiliki kebutuhan yang khas dan kepribadian unik untuk bekerja sama menuju pencapaian sasaran-sasaran organisasi mereka. Menurut Hasibuan (2001) motivasi adalah pemberian daya penggerak yang menciptakan kegairahan kerja seseorang, agar mau bekerjasama, bekerja efektif, dan terintegrasi dengan segala daya upayanya untuk mencapai kepuasan.

David C. McClelland (dalam Mangkunegara, 2005), mengemukakan bahwa produktivitas seseorang sangat ditentukan oleh "virus mental" yang ada pada dirinya. Virus mental adalah kondisi jiwa yang mendorong seseorang untuk mampu mencapai prestasinya secara maksimal. Ada 3 faktor atau dimensi dari motivasi menurut McClelland (dalam Mangkunegara, 2005) yaitu motif, harapan, dan insentif.

Motif adalah suatu prangsang keinginan dan daya penggerak kemauan bekerja. Setiaf motif mempunyai tujuan tertentu yang ingin dicapai. Indikator dari motif ini sendiri adalah sebagai berikut. a) kebutuhan ekonomis, b) rasa aman dalam bekerja, c) Kepuasan melaksanakan pekerjaan, d) mengembangkan diri dalam berkarir dan memperoleh kemajuan, e) rasa ingin tahu akan pekerjaan, f) menggunakan cara-cara baru, g) melaksanakan suatu pekerjaan dengan rekan-rekan kerja. Harapan

merupakan kemungkinan mencapai suatu dengan aksi tertentu. Seorang karyawan di motivasi untuk menjalankan tingkat upaya tinggi bila karyawan meyakini upaya tersebut akan menghantar kesuatu penilaian kinerja yang baik, suatu penilaian yang baik akan mendorong ganjaran-ganjaran organisasional seperti bonus, kenaikan gaji, atau promosi, dan ganjaran itu 
akan memuaskan tujuan pribadi karyawan. Indikator untuk mengukur harapan adalah sbagai berikut. a) adanya kebijakan atasan, b) adil dalam segala bidang, c) rasa aman dalam bekerja, d) adanya penghargaan prestasi kerja.

Insentif yang diberikan kepada karyawan sangat berpengaruh terhadap motivasi dan produktivitas kerja. Indikator dari insentif ini adalah sebagai berikut. a) gaji yang sepadan, b) pemberian bonus.

Menurut Mathis dan Jackson (2006:378) kinerja karyawan yang umum untuk kebanyakan pekerjaan meliputi elemen sebagai berikut kuantitas dari hasil, kualitas dari hasil, ketepatan waktu dari hasil, kehadiran, dan kemampuan bekerja sama. 1) Kuantitas dari hasil yaitu Jumlah yang harus diselesaikan atau dicapai. Pengukuran kuantitatif melibatkan perhitungan keluaran dari proses atau pelaksanaan kegiatan. Ini berkaitan dengan jumlah keluaran yang dihasilkan. 2) Kualitas dari hasil adalah mutu yang harus dihasilkan (baik tidaknya). Pengukuran kualitatif keluaran mencerminkan pengukuran tingkat kepuasan, yaitu seberapa baik penyelesaiannya. Ini berkaitan dengan bentuk keluaran. 3) ketepatan waktu dari hasil adalah waktu harus dimanfaatkan sebaik mungkin dan secara optimal. Penundaan penggunaan waktu dapat menimbulkan berbagai konsekuensi biaya besar dan kerugian. 4) Kehadiran atau absensi ialah tingkat kehadiran merupakan sesuatu yang menjadi tolak ukur sebuah perusahaan dalam mengetahui tingkat partisipasi karyawan pada perusahaan. 5) Kemampuan bekerja sama adalah kemampuan bekerja sama dapat menciptakan kekompakan sehingga dapat meningkatkan rasa kerja sama antar karyawan.

$$
\text { Menurut Nawawi }
$$

kepentingan para pemimpin terhadap kemampuan kerja seorang karyawan cenderung terpusat pada kinerja karyawan. Pandangan ini mengenai hubungan antara kemampuan kerja karyawan dengan kinerja pada hakekatnya dapat diringkas dalam pernyataan "seorang pekerja yang bahagia adalah seorang pekerja yang produktif" banyak yang dilakukan oleh para pemimpin dalam membuat para pekerjanya merasa senang dalam pekerjaannya. Menurut Robbins (2004:218), kinerja individu di tempat kerja tidak hanya tergantung pada kemampuannya, tetapi juga pada motivasi yang dimilikinya. Kinerja tidak bisa diperoleh hanya dengan memiliki kemampuan saja, karena hal ini tidak akan berarti apa-apa jika di dalam diri karyawan tidak ada keinginan atau motivasi untuk bekerja dengan baik pula.

Penelitian yang dilakukan oleh Ardiana (2014) tentang bagaimana kemampuan dan motivasi kerja mempengaruhi kinerja pegawai menyebutkan bahwa kemampuan mempengaruhi kinerja pegawai secara langsung sebesar $14.9 \%$, sedangkan pengaruh secara langsung motivasi terhadap kinerja adalah sebesar $27.3 \%$, jika di jumlah maka kedua variabel tersebut memiliki pengaruh sebesar $41.2 \%$ terhadap kinerja pegawai. Dari pemaparan di atas dapat disimpulkan bahwa kinerja dapat di pengaruhi oleh dua faktor yaitu kemampuan dan motivasi.

Oriflame merupakan bisnis Multi Level Marketing (MLM) produk kecantikan yang tidak lepas dari faktor tersebut di atas, karena bisnis MLM merupakan bisnis yang sangat bergantung kepada membernya untuk menjual dan memasarkan produknya, dengan mengingat hal tersebut maka Oriflamme sangat mengedepankan kualitas dan kemampuan tiap membernya dengan memberikan pelatian mengenai produk serta berbagai macam cara pemasaran kepada tiap membernya. Selain memberikan pelatihan untuk meningkatkan kemampuan membernya, Oriflame juga selalu memberikan bonus berupa barang dan uang diluar keuntungan penjualan produk kepada para membernya, namun terdapat 
perbedaan kemampuan membernya dari satu dengan yang lainnya untuk meningkatkan "level-nya" di Oriflame.

Sejak tahun 1986 dan hingga saat ini, Oriflame sudah memiliki 14 kantor cabang di seluruh Indonesia, daerah Bali salah satunya memiliki kantor cabang di kota Denpasar, dengan 3 jaringan besar yang dimiliki oleh Oriflame cabang Denpasar terdapat beberapa grup yang kemampuan membernya untuk meningkatkan level terlihat lebih lambat dibandingkan grup lainnya, dengan pelatihan yang sama yang diberikan oleh Oriflame setiap bulannya kepada para membernnya seharusnya setiap membernnya sudah memiliki kemampuan yang cukup untuk menjalankan bisnisnya, selain itu dengan melihat keadaan ekonomi sekarang, dimana sangat sulit dalam mencari lapangan pekerjaan yang hasilnya sesuai untuk mencukupi kebutuhan hidup.

Motivasi berupa bonus yang diberikan oleh Oriflame tiap bulannnya kepada member yang mencapai tingkat penjualan tertentu, sudahlah lebih dari cukup untuk memberikan motivasi kepada membernya untuk meningkatkan kinerja mereka, selain itu dengan mengacu kepada indikator kinerja yang baik sesuai dari teori yang disampaikan oleh Mathis dan Jackson (2006) diantaranya, proses kerja dan waktu yang dipergunakan untuk menjalankan bisnis ini yang kurang, hal ini dikarenakan beberapa member hanya menganggap bisnis Oriflame adalah bisnis sampingan, hal ini juga mempengaruhi ketepatan waktu member tersebut dalam menyelesaikan tugasnya. Tingkat kehadiran dalam kegiatan yang dilakukan seperti training dan kerja bersama sangat kurang sehingga tingkat kerja sama dalam grup ini juga dianggap kurang baik. Dari pemaparan di atas, maka peneliti tertarik untuk mencoba melakukan penelitian pada salah satu grup Oriflame mengenai, "Pengaruh Kemampuan Kerja dan Motivasi Kerja Terhadap Kinerja member Bisnis Oriflame".

\section{METODE}

Jenis penelitian ini adalah penelitian kausal yang menguji hubungan sebab akibat antara dua variabel. Menurut Sugiyono (2012) metode kausal adalah hubungan yang bersifat sebab akibat, sehingga terdapat variabel independent (variabel yang mempengaruhi) yaitu kemampuan kerja serta motivasi kerja, dan variabel dependen (dipengaruhi) yaitu kinerja member Oriflame. Adapun jenis data dari penelitian ini adalah data kuantitatif, yaitu data yang dapat diimput ke dalam skala pengukuran statistik dan disajikan dalam angka-angka (Sugiyono, 2012).

Sumber data yang digunakan bersumber dari data premier berupa kuesioner yang akan disebarkan kepada narasumber dan data sekunder berupa activity report. Data pada penelitian ini ambil dengan menyebarkan angket berupa kuesioner kepada responden, dalam hal ini member Oriflame di Bali pada salah satu grup. Populasi dalam penelitian ini adalah member Oriflame di Bali yang masih aktif pada bulan Januari sampai dengan Maret 2017 pada satu grup, berjumlah 124 orang. Sampel pada penelitian ini berjumlah 95 orang ditentukan dengan mengunakan rumus Slovin. Metode pengumpulan sampelnya menggunakan teknik probability sampling dengan metode disproportionate areal random sampling. Disproportionate areal random sampling adalah teknik pengambilan sampel dari anggota populasi pada beberapa daerah secara tidak proporsional dikarenakan jumlah populasi sampel pada daerah tertentu lebih sedikit jumlahnya dibandingkan daerah lain, maka populasi pada daerah tersebut akan diambil semua sebagai sampel.

Teknik pengumpulan data pada penelitian ini dilakukan dengan mengunakan kuisioner yang dirancang menggunakan Skala Likert, yang menurut Sugiyono (2012), kuisioner adalah alat ukur yang digunakan untuk mengukur sikap, pendapat, persepsi seseorang atau kelompok orang 
tentang suatu fenomena sosial. Adapun penjabaran kuisioner yang telah dirancang menggunakan Skala Likert sebagai berikut. 1) Apabila pertanyaan sangat sering (SS) diberi skor 5. 2) Apabila pertanyaan sering (S) diberi skor 4. 3) Apabila pertanyaan kadangkadang (KK) diberi skor 3. 4) Apabila pertanyaan jarang (J) diberi skor 2. 5) Apabila pertanyaan tidak pernah (TP) diberi skor 1.

Instrumen dalam penelitian ini berupa kuisioner untuk menjabarkan indikator dari variabel penelitian, maka perlu dilakukan pengujian guna mengukur tingkat validitas dan reabilitasnya. Menurut Sugiyono (2012), validitas merujuk sejauh mana instrumen dapat digunakan untuk mengukur apa yang hendak diukur, sedangkan reliabilitas merujuk pada sejauhmana instrumen pengukur dapat dipercaya atau diandalkan. Instrumen yang valid berarti alat ukur yang digunakan untuk mendapatkan data (mengukur) itu valid, valid berarti instrument tersebut dapat digunakan untuk mengukur apa yang seharusnya diukur.

Noor (2014:19) menyampaikan ada empat pokok dari uji validitas dari sebuah kuisioner, empat pokok tersebut yaitu 1) uji ini sebenarnya untuk melihat kelayakan butir - butir pertanyaan dalam kuisioner agar dapat mendefinisikan variabel tertentu, 2) daftar pertanyaan ini pada umumnya untuk mendukung suatu kelompok variabel tertentu, 3) uji validitas dilakukan setiap butir soal. Hasilnya dibandingkan dengan $r_{\text {tabel }} l \quad \mathrm{df}=\mathrm{n}=\mathrm{k}$ dengan tingkat kesalahan 5\%, dan 4) Jika $r_{\text {tabel }}<r_{\text {hitung, }}$, maka butir soal disebut valid.

Reliabilitas menunjuk pada satu pengertian bahwa suatu instrumen dapat dipercaya untuk digunakan sebagai alat pengumpul data karena instrumen tersebut sudah baik (Arikunto, 2005). Uji reliabilitas dihitung dengan koefisien alpha cronbach adalah kefisien keandalan yang menunjukan seberapa baiknya item butir dalam suatu kumpulan secara positif berkorelasi satu sama lain (Juliansyah Noor, 2014). Instrumen yang reliabel adalah instrument yang bila digunakan beberapa kali untuk mengukur objek yang sama, akan menghasilkan data yang sama (Sugiyono, 2012).

Sesuai dengan rumusan masalah dan tujuan penelitian maka analisis data yang di gunakan adalah regresi linier berganda, untuk itu terlebih dahulu dilakukan uji asumsi klasik berupa uji normalitas, uji multikolinearitas, uji heteroskedastisitas dan uji autokorelasi.

Uji normalitas, untuk menguji normalitas residual dengan uji statistik non parametrik Kolmogorov Smirnov (KS). suatu model dikatakan berdistribusi normal jika nilai signifikansi $>\alpha=0,05$ dan sebaliknya suatu model dikatakan tidak berdistribusi normal jika nilai signifikansi $<\alpha=0,05$.

Uji multikolinearitas, adalah untuk mengetahui apakah terdapat korelasi antara variabel bebas $\left(X_{1}\right.$ dan $\mathrm{X}_{2}$ ), dengan uji Farrar-Glauber (perhitungan ratio- $F$ untuk menguji lokasi multikolinearitas). Hasil dari $F_{\text {statistik }}(\mathrm{Fi})$ dibandingkan dengan $\mathrm{F}_{\text {tabel. }}$. Kriteria pengujiannya adalah apabila $\mathrm{F}_{\text {tabel }}>\mathrm{Fi}$ maka variabel bebas tersebut kolinear terhadap variabel lainnya. Sebaliknya, jika $F_{\text {tabel }}<\mathrm{Fi}$, maka variabel bebas tersebut tidak kolinear terhadap variabel bebas yang lain.

Uji heteroskedastisitas, adalah uji yang dilakukan untuk mengetahui terjadinya gangguan dalam fungsi regresi yang mempunyai varian yang tidak sama. Heteroskedastisitas di uji dengan menggunakan uji Park. Kriteria pengujiannya adalah apabila $t_{\text {hitung }}<$ $t_{\text {tabel, maka antara variabel tidak }}$ terdapat heteroskedastisitas terhadap nilai residual lain, atau bias disebut varian residual regresi ini adalah homogen.

Uji autokorelasi, adalah untuk mengetahui korelasi antara variabel gangguan sehingga penaksir tidak lagi efisien. Dengan melakukan percobaan Durbin-Watson, yaitu apabila nilai Durbin Watson $<\mathrm{F}_{\text {tabel}}$, maka diantara 
variabel bebas tidak terdapat autokorelasi.

\section{HASIL PENELITIAN DAN \\ PEMBAHASAN \\ Hasil Penelitian}

Hasil daripada penelitian mengenai pengaruh kemampuan kerja dan motivasi kerja terhadap kinerja member bisnis Oriflame untuk mengetahui seberapa besar masing- masing variabel bebas mempengaruhi kinerja member serta seberapa besar kedua variabel bebas secara bersamasama mempengaruhi kinerja member Oriflame.

Untuk mengetahui lebih jelas mengenai hasil uji pengaruh variabel kemampuan kerja (X1) terhadap kinerja member Oriflame (Y) secara parsial dengan bantuan SPSS dapat dilihat pada tabel 1.

Tabel 1. Hasil Uji Koefisien Kemampuan Kerja

\begin{tabular}{|c|c|c|c|c|c|c|}
\hline & \multirow[b]{2}{*}{ Model } & \multicolumn{2}{|c|}{$\begin{array}{l}\text { Unstandardized } \\
\text { Coefficients }\end{array}$} & $\begin{array}{l}\text { Standardized } \\
\text { Coefficients }\end{array}$ & \multirow[b]{2}{*}{$t$} & \multirow[b]{2}{*}{ Sig. } \\
\hline & & $\mathrm{B}$ & Std. Error & Beta & & \\
\hline \multirow[t]{2}{*}{1} & (Constant) & 7.368 & 1.811 & & 4.068 & .000 \\
\hline & Kemampuan Keria & .212 & .096 & .270 & 2.202 & .030 \\
\hline
\end{tabular}

Dari tabel 1 diatas dapat dilihat $t_{\text {hitung }}$ dari variabel kemampuan kerja (X1) sebesar 2.202, jika dibandingkan dengan $t_{\text {tabel }} d F=N-K$, dimana $N$ adalah jumlah data sedangkan $\mathrm{K}$ adalah banyaknya variabel, $\mathrm{dF}=95-3$ yaitu 1.66140 maka $2.202>1.66140 \mathrm{H}_{0}$ ditolak dan $\mathrm{H}_{1}$ diterima, ada pengaruh yang signifikan dari kemampuan kerja terhadap kinerja member Oriflame. Pengaruh yang diberikan oleh variabel kemampuan kerja (X1) kepada kinerja
(Y) adalah sebesar 0.212 atau apabila kemampuan kerja meningkat nilainya sebanyak satu, maka kinerja member akan meningkat sebesar 0.212 . Koefisien bernilai positif artinya terjadi hubungan yang searah antara kemampuan kerja terhadap kinerja.

Untuk mengetahui lebih jelas mengenai hasil uji pengaruh variabel motivasi kerja (X2) terhadap kinerja member Oriflame $(\mathrm{Y})$ dapat dilihat pada tabel 2.

Tabel 2. Hasil Uji Koefisien Motivasi

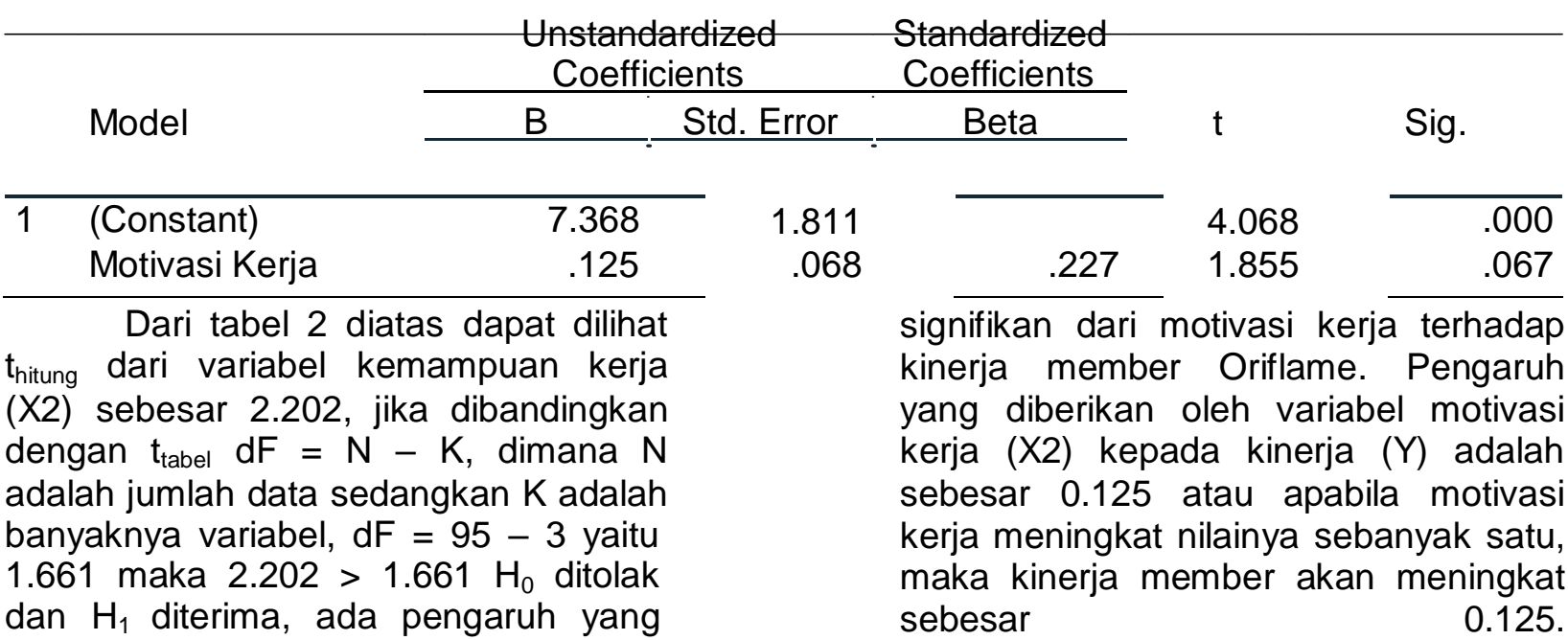


Uji koefisien regresi secara simultan dilakukan untuk mengetahui besarnya pengaruh yang ditimbulkan oleh variabel bebas secara bersamasama terhadap variabel terikat. Untuk mengetahui lebih jelas mengenai hasil uji koefisien pengaruh kemampuan kerja (X1) dan motivasi kerja (X2) terhadap kinerja member Oriflame $(Y)$ dapat dilinat pada tabel 3 .

Tabel 3. Hasil Uji Koefisien Regresi Simultan (Uji F)

\begin{tabular}{|c|c|c|c|c|c|c|}
\hline \multirow{4}{*}{1} & & Sum of Squares & $\mathrm{df}$ & Mean Square & $\mathrm{F}$ & Sig. \\
\hline & Regression & 153.411 & 2 & 76.721 & 11.782 & $.000^{6}$ \\
\hline & Residual & 599.085 & 92 & 6.512 & & \\
\hline & Total & 752.526 & 94 & & & \\
\hline
\end{tabular}

Dari tabel 3 diatas didapatkan $F_{\text {hitung }}$ sebesar 11.782 yang mana jika di bandingkan dengan $\mathrm{F}_{\text {tabel }}$ dengan taraf signifikansi $5 \%$ adalah $11.782>3.09$ dan Sig sebesar $0.000<0.05$ maka $\mathrm{H}_{1}$ diterima yaitu terdapat pengaruh yang signifikan dari kemampuan kerja dan motivasi kerja secara bersama - sama terhadap kinerja member Oriflame.

\section{Pembahasan}

Berdasarkan hasil penelitian dan pengujian hipotesis mengenai pengaruh kemampuan kerja dan motivasi kerja terhadap kinerja member Oriflame diketahui bahwa terdapat pengaruh yang signifikan dari kemampuan kerja $\left(X_{1}\right)$ terhadap kinerja member Oriflame (Y). Besarnya koefesien regresi variabel kemampuan kerja sebesar 0.212 artinya apabila nilai kemampuan kerja meningkat sebesar satu maka kinerja member Oriflame akan meningkat sebesar 0.212. Pengaruh kemampuan kerja bernilai postif yang artinya terjadi hubungan yang searah antara kemampuan kerja terhadap kinerja. Hasil ini sesuai dengan penelitian terdahulu yang dilakukan oleh Ardiana (2014), dimana dalam penelitiannya menyatakan bahwa besarnya pengaruh langsung kemampuan kerja terhadap kinerja pegawai sebesar 14,9\%.

Pada penelitian ini didapatkan pengaruh yang signifikan dari motivasi kerja $\left(X_{2}\right)$ terhadap kinerja member Oriflame (Y). Pengaruh yang diberikan oleh variabel motivasi kerja kepada kinerja adalah sebesar 0.125 atau apabila motivasi kerja meningkat nilainya sebanyak satu, maka kinerja member akan meningkat sebesar 0.125 , pengaruh yang ditimbulkan oleh motivasi kerja bersifat positif. Hasil penelintian ini sesuai dengan penelitian yang dilakukan oleh Aruan (2013) yang mana pada penelitiannya mendapatkan faktor motivasi kerja mempengaruhi kinerja pegawai sebesar $37.21 \%$.

Hasil terakhir yang didapatkan dari hasil pengujian yaitu terdapat pengaruh yang signifikan dari kemampuan kerja $\left(X_{1}\right)$ dan motivasi kerja $\left(X_{2}\right)$ secara bersama-sama terhadap kinerja member Oriflame $(\mathrm{Y})$, besarnya sumbangan pengaruh yang diberikan oleh variabel kemampuan kerja serta motivasi kerja terhadap kinerja member Oriflame adalah sebesar $20.4 \%$ sedangkan sisanya sebesar $79.6 \%$ dipengaruhi faktor lain yang tidak diteliti. Hasil penelitian ini sesuai dengan pendapat yang dikemukakan oleh Makunegara (2005:13-14), yaitu terdapat 2 faktor yang mempegaruhi kinerja pegawai yaitu yang pertama adalah faktor kemampuan dan yang kedua adalah faktor motivasi.

\section{SIMPULAN DAN SARAN Simpulan}

Berdasarkan hasil analisis data dan pembahasan, maka dapat ditarik simpulan sebagai berikut. (1) Ada pengaruh yang signifikan dari kemampuan kerja terhadap kinerja member Oriflame. Besarnya koefesien 
regresi variabel kemampuan kerja sebesar 0.212. (2) Ada pengaruh yang signifikan dari motivasi kerja terhadap kinerja member Oriflame. Besarnya koefesien regresi variabel motivasi kerja adalah sebesar 0.125. (3) Ada pengaruh yang signifikan dari kemampuan kerja dan motivasi kerja secara bersama - sama terhadap kinerja member Oriflame. Besarnya sumbangan pengaruh yang diberikan oleh variabel kemampuan kerja serta motivasi kerja terhadap kinerja member Oriflame adalah sebesar $20.4 \%$.

\section{Saran}

Berdasarkan pembahasan dan simpulan diatas, maka saran yang dapat diberikan untuk member Oriflame adalah agar lebih meningkatkan kemampuan kerja masing-masing individu dengan mengikuti training maupun kegiatan yang bertujuan untuk menambah pengetahuan individu yang diadakan baik oleh upline maupun oleh Oriflame, selain itu member diharapkan mampu meningkatkan keterampilan lain yang dapat membantu member untuk melaksanakan

contohnya dengan meningkatkan ketrampilan dalam mengunakan komputer serta pemamfaatan internet. Bagi Oriflame diharapkan tetap memberikan pelatihan yang mampu meningkatkan kemampuan tiap member Oriflame, yang mana dengan meningkatnya kemampuan member maka akan berdampak pada kinerja tiap membernya. Oriflame diharapakan tetap mampu memberikan motivasi dari segi bonus dan reward sehingga mampu meningkatkan kinerja membernya. Bagi peneliti lain yang ingin melakukan penelitian dibidang kinerja, diharapkan mampu melakukan pengembangan dan penelitian lebih lanjut mengenai faktorfaktor yang mempengaruhi kinerja. Hal ini berguna untuk menguji keberlakuan temuan mengenai faktor-faktor yang mempengaruhi kinerja.

\section{DAFTAR PUSTAKA}

Ardiana, I. Putu, I. Made Nuridja, and S. Pd Luh Indrayani. 2014.
"Pengaruh Kemampuan Kerja dan Motivasi Kerja Terhadap Kinerja Pegawai Pada Balai Penelitian dan Observasi Laut (BPOL)". Jurnal- Jurusan Pendidikan Ekonomi. Vol. 4, No. 1, 6-8.

Arikunto. 2005. Manajemen Penelitian. Jakarta: Rineka Cipta.

Aruan, D. A. 2013. "Pengaruh Pelatihan Kerja dan Motivasi terhadap Kinerja Karyawan PT. Sucofindo (Persero) Surabaya". Jurnal IImu Manajemen, Vol. 1, No. 2, 566574.

Coulter, Robbins. 2004. Manajemen, Edisi Ketujuh, Edisi Indonesia, Jilid Kesatu. Jakarta: PT. Indeks Group Gramedia.

Hadari Nawawi. 2003. Manajemen Sumber Daya Manusia Untuk Bisnis Kompetitif. Yogyakarta: Gadjah Mada University Press.

Hasibuan, Malayu. 2001. Manajemen Sumber Daya Manusia: Pengertian Dasar, Pengertian, dan Masalah. Jakarta: PT. Toko Gunung Agung,

Mangkunegara, A. A. Anwar Prabu. 2005. Evaluasi Kinerja Sumber Daya Manusia. Cetakan I. Bandung: PT Refika Aditama. 2007. Manajemen Sumber Daya Manusia Perisahaan, Cetakan Ketujuh. Bandung: Remaja Rosda Karya.

Mathis Robert L. dan Jackson John $\mathrm{H}$. 2006. Human Resource Management, alih bahasa. Jakarta: Salemba Empat.

Moenir. 2002. Manajemen Pelayanan Umum Indonesia. Jakarta: Bumi Aksara.

Noor, Juliansyah. 2014. Analisis Data Penelitian Ekonomi \& Manajemen. Jakarta: PT Gramedia Widia Sarana.

Rivai, Veithzal, dan Basri. 2005. Performance Appraisal. Cetakan Pertama, Jakarta: PT Raja Grafindo Persada.

Robbins, \& Stephen. 2008. Perilaku Organisasi Buku 1, Jakarta: Salemba Empat. 
Soehardi. 2003. Esensi Perilaku Organisasional. Yogyakarta: Bagian Penerbit Sajanawiyata Tamansiswa.

Sugiyono. 2012. Metode Penelitian Kuantitatif Kualitatif dan $R$ \& $D$. Bandung: Alfabeta.

Sulistiyani dan Rosidah. 2003. Manajemen Sumber Daya Manusia. Yogyakarta: Graha IImu.

Sutrisno. 2007. Manajemen Keuangan Teori, Konsep, dan Aplikasi. Yogyakarta: EKONISIA.

Winardi, J. 2002. Motivasi dan Permotivasian Dalam Manajemen. Jakarta: PT RajaGrafindo Persada. Jakarta: 2007. Manajemen Kinerja, Persada. 